\title{
Review
}

\section{Foodborne disease outbreaks in Barbados (1998-2009): a 12-year review}

\author{
Carol Hull-Jackson ${ }^{1}$, Abiodun A Adesiyun ${ }^{1}$ \\ ${ }^{1}$ School of Veterinary Medicine, The University of the West Indies, St. Augustine, Trinidad and Tobago, West \\ Indies
}

\begin{abstract}
Introduction: Microbes such as Salmonella, Campylobacter and S. aureus have been implicated in Foodborne disease outbreaks (FBDOs) worldwide, yet information on their occurrence in Barbados is scanty. The purpose of this study was to determine the aetiological agents, food vehicles, locations and peak seasons of FBDOs in Barbados; assess the quality of epidemiological investigations; and identify deficiencies in food production practices and laboratory detection.

Methodology: A search of FBDOs occurring in Barbados between 1998-2009 was conducted among published and unpublished literature sources and reports. The search terms included the keywords "foodborne disease," "outbreaks" and "Barbados".

Results: During the period 1998 to 2009, there were 24 foodborne outbreaks, 215 cases of illness, one hospitalisation and no deaths. Overall, $37.5 \%$ of outbreaks were associated with hotels/resorts. Salmonella Enteritidis phage type 8 was most commonly implicated with eggs and poultry being the primary vehicles. Three outbreak reports were available for assessment and revealed that there were deficiencies in the outbreak investigations. These reports also recorded high levels of food contamination with indicator organisms, suggesting that improvements in food hygiene and production practices were required.

Conclusions: The number of FBDOs is low in comparison to developed countries. However, the data was likely affected by under-reporting and inadequacies in the outbreak investigations and laboratory detection. Improvements in these areas would lead to not only better detection and characterisation of FBDOs in Barbados but improved food safety control measures.
\end{abstract}

Key words: Foodborne disease outbreaks; Barbados; epidemiological investigations.

J Infect Dev Ctries 2019; 13(1):1-10. doi:10.3855/jidc.10404

(Received 27 March 2018 - Accepted 13 November 2018)

Copyright (C) 2019 Hull-Jackson et al. This is an open-access article distributed under the Creative Commons Attribution License, which permits unrestricted use, distribution, and reproduction in any medium, provided the original work is properly cited.

\section{Introduction}

Foodborne disease outbreaks (FBDOs) present a global problem which results in illnesses and deaths in humans and animals, and a negative impact on the economies. In 2015, among humans in the U.S.A., there were 902 FBDOs resulting in 15,202 illnesses, 950 hospitalisations and 15 deaths [1]. In these U.S.A outbreaks, Norovirus followed by Salmonella (serovars Enteritidis and Typhimurium), Shiga toxin producing E. coli and Campylobacter spp. were the major pathogens responsible. In Hong Kong, a 10-year review conducted from 1996 to 2005, revealed that there were 5,967 FBDOs resulting in 26,260 cases and 1,854 hospitalisations [2]. However, contrary to the U.S.A., in Hong Kong, Vibrio parahaemolyticus (47\%) Salmonella spp. (25\%), S. aureus (7.7\%) and Noroviruses $(6.8 \%)$ were responsible for most confirmed outbreaks as a result mainly of inadequate cooking and contamination by raw food [2]. Subsequently, there was an overall decrease in the occurrence of FBDOs in Hong Kong between 2006 to 2016, due in part to the government's vigilance in safeguarding food safety [3]. In a Singaporean study $(2001-2010)$ at least 100,000 persons per annum were affected by FBDOs. Bacteria and their toxins were responsible for over $90 \%$ and Salmonella Enteritidis (SE) was the predominant serovar [4]. Similarly, reviews conducted in Australia (2011 and 2016), revealed that bacteria accounted for the majority of outbreaks, with the most frequently implicated bacterial pathogens being Salmonella spp. (29 - 40\%), in particular, serovar Typhimurium, followed by Campylobacter spp. (3 - 7\%) [5,6].

Although the aforementioned studies have examined FBDOs in developed nations, a study which investigated FBDOs in the developing nation of Kenya reported a low number of outbreaks (37) of which the aetiologies were confirmed in only $13(35 \%)$, which affected 926 persons [7]. However, the Kenyan review's coverage was limited by under-reporting and laboratory deficiencies [7]. By contrast, another study conducted in Iran, another developing nation, reported that there were 2,250 FBDOs over a 6-year period (2006 - 2011). The incidence of outbreaks increased 
from 0.07 per 100,000 in 2006 to 1.38 per 100,000 population in 2011 due largely to improved detection and surveillance [8].

Foodborne diseases (FBD) are the illnesses transmitted by ingested food. In the developing region of the Caribbean, they are notifiable and there has been an increase in related cases and the public health and economic impact from 2005 to 2014 [9]. Furthermore, a high incidence of FBD has been associated with microbial pathogens [10] and food producing animals within the region [9]. Nevertheless, of the 42,973 cases of FBD reported within the region between the periods $1981-2005$, only $1 \%$ was documented as having occurred in Barbados with most cases occurring in Trinidad and Tobago (38\%) [11]. However, gathering accurate information and data on the incidence of foodborne illness has been limited by inadequate surveillance, under-reporting and the absence of laboratory confirmation [10]. To address these issues, in 2006, the World Health Organization (WHO) commenced a global initiative to estimate the global burden of foodborne disease [12-14]. Subsequently, burden of illness (BOI) studies were performed within the Caribbean region in order to determine the impact of acute gastroenteritis (AGE), a syndrome of FBD, characterised by the occurrence of 3 or more loose stools or vomiting in 24 hours [15-21]. In Barbados, one such study was conducted $(2010$ - 2011) as a population survey among 1,710 randomly selected households [21]. An AGE prevalence of $4.9 \%$ with an annual incidence rate of 0.65 episodes per person were reported and it was found that the public health burden and impact of AGE in Barbados was high. However, a high under-reporting rate (98\%) was recorded [21]. In addition to these BOI studies, there were reports on Salmonella, Shigella, Campylobacter and Rotavirusassociated enteritis in Barbados [22-25] and the microbiological contamination of foods in the Caribbean [26-34]. However, only one study [24] reported on FBDOs. Consequently, there is a dearth of information on the true incidence of FBDOs within the Caribbean region.

FBDO studies can yield slightly different information on the aetiology and food types involved when compared with AGE prevalence studies. Moreover, such studies can provide information regarding gaps in outbreak investigations, which can be addressed. In addition, many Caribbean economies rely heavily on tourism. It should be emphasized that travellers' diarrhoea (TD) affects $20-60 \%$ of international travellers with $50-80 \%$ being of bacterial aetiology [35]. Furthermore, the Caribbean has been classified as a moderate to high-risk region for the acquisition of TD [36] yet only a few published reports exist on diarrhoeal illnesses involving tourists in the Caribbean [37-41]. While the information reported in some of these studies was used to improve food safety within the local hotel industry and to educate food handlers, once more, reports on FBDOs were not included. In Barbados, tourism has been a major contributor to the economy since the late 1970's employing 17,000 people (13.3\% of total employment) and contributing $12.9 \%$ of the total GDP [42]. As the Barbadian economy cannot withstand a negative impact on the tourism industry, characterisation of FBDOs is important. Additionally, knowledge of the deficiencies in food handling practices and epidemiological investigations can assist in identifying areas for improvement. Therefore, the primary aims of this investigation were to examine FBDOs occurring in Barbados with regards to the incidence, major pathogens, food vehicles, locations and the peak seasons. Furthermore, the quality of the epidemiological investigations, laboratory proficiency and documentation of FBDOs in Barbados were assessed.

\section{Methods}

\section{Literature search}

A search of the published literature in peerreviewed journals was conducted among the bibliographic databases of NCBI Medline, Research Gate, Google Scholar, ISI Web of Science and the EBSCOhost databases of the University of the West Indies Libraries (U.W.I, St. Augustine and Cave Hill Campuses). Online databases of the CARPHA, PAHO and CDC were also searched for annual and periodic reports. The search terms utilised were "foodborne," "illness," “outbreaks", "tourists", "hospitality industry", "hotels" "reviews", "Barbados" and those of specific pathogens such as "Salmonella", "Campylobacter", "Shigella" and "S. aureus". Additionally, a search was conducted throughout the database of the library of the Ministry of Health and the Barbados Association of Medical Practitioners (B.A.M.P). The literature for appraisal incorporated both published and unpublished sources.

\section{Consultations}

Senior Officials within the Ministry of Health, Barbados were consulted concerning the study in order to ascertain the location and scope of the records that were to be reviewed. There were eight polyclinics responsible for various catchment areas with respective 
Medical Officers of Health or Senior Environmental Health Officers serving as key contact persons at each polyclinic. Six of the major polyclinic catchments (Warrens, St. Phillip, Maurice Byer, Brandford Taitt, Winston Scott and Randall Phillips) including those along the tourist belt, were examined for this study. Personnel within the Ministry of Health's Epidemiology and Environmental Health Units and the Polyclinics were asked to provide details and documented reports concerning outbreaks (1998-2009) including: date of onset and duration of the outbreak; setting of the outbreak e.g. hotel, hospital or offices; type of food business/operator e.g. mobile food vendor, restaurant, caterer; number of cases (including the number of visitors), attack rates, severity (hospitalisation/deaths) and treatments; source of the outbreak (confirmed or suspected) e.g. food, water; food vehicles e.g. poultry (eggs, chicken), fish, lamb; laboratory confirmation: types and numbers of samples submitted for laboratory testing and organisms isolated.

\section{Inclusion criteria}

A FBDO was defined as any incident where two or more cases of a similar foodborne disease occurred as a result of the ingestion of a common food. Therefore, all published and unpublished literature of foodborne outbreaks that met the above definition and could be confirmed by epidemiological and/or microbiological (laboratory) evidence were included in the review. If a foodborne pathogen had not been identified in an outbreak but there was sufficient epidemiological evidence to support the occurrence of a foodborne outbreak, it was included in the analysis. Reports were excluded from the review if they did not meet the definition of a foodborne outbreak, were outside of the study period or had neither epidemiological nor microbiological evidence of foodborne transmission.

\section{Ethics approval}

Written approval was granted by the University of the West Indies, Institutional Review Board and the Ministry of Health, Barbados.

\section{Data management and statistical analyses}

Summary information was entered firstly into Excel 2010 (Microsoft Corporation) and then into the Statistical Package for Social Sciences (SPSS), version 23.0 (IBM, Armonk, NY, USA). Descriptive statistics included frequencies and measures of central tendency such as the mean and median. The Chi-squared test of significance was performed to determine which frequencies were significant at a level of $\mathrm{P} \leq 0.05$.

\section{Results}

The information independently verified by the Ministry of Health indicated that there were 24 foodborne outbreaks, which resulted in 215 cases of illness, one hospitalisation and no deaths during the period 1998 to 2009 (Table 1). The mean number of FBDOs was $2(\mathrm{SD}=2.1)$ per annum and $0.75(\mathrm{SD}=$ $0.78)$ per 100,000 persons per annum. The mean number of cases associated with the verified FBDOs was $17.9(\mathrm{SD}=18)$ per annum and $6.6(\mathrm{SD}=6.6)$ per 100,000 persons per annum. Fifty-four $(25.1 \%)$ of the total cases were visitors. Twenty $(83.3 \%)$ of the 24 outbreaks were solved where both the causative organism and a food source were identified and confirmed by the laboratory. Two $(8.3 \%)$ were partially solved where only the causative organisms were laboratory confirmed from clinical specimens and two $(8.3 \%)$ were unsolved where either the causative organism and/or the source were not laboratory confirmed but there was sufficient epidemiological evidence to support the occurrence of a foodborne outbreak. A general decline was observed in the number of outbreaks from 1998 to 2008, with a peak occurring in 1999.

\section{Location, setting and source of FBDOs}

For seven $(29.2 \%)$ of 24 outbreaks involving 114 cases, the location was documented. The majority (3/7 $(42.9 \%), 72$ cases) occurred in the catchment of the Winston Scott Polyclinic (WSPC) and Brandford Taitt Polyclinic (BTPC) (3/7 (42.9\%), 36 cases) which both occurred along the tourist belt and the least frequency was in Warrens Polyclinic (WPC) (1/7 (14.3\%), six cases), which, due to its location around residential neighbourhoods provides mostly community-based health care (Table 1). There was no significant association between the location and number of outbreaks $\left(\chi^{2}(2)=1.14, \mathrm{P}>0.05\right)$. Concerning the setting, of the 24 FBDOs, the majority were associated with households $-11 / 24(45.8 \%)$, followed by hotels 9/24 (37.5\%), private businesses (workplaces) - 2/24 (8.3\%), food business $-1 / 24(4.2 \%)$ and hospitals $1 / 24(4.2 \%)$. However, these differences were not statistically significant. Concerning the source, home kitchens were most associated with outbreaks, 11/24 (45.8\%), followed by hotel restaurants - 8/24 (33.3\%), other food businesses $4 / 24(16.7 \%)$ and hospital kitchens $1 / 24$ (4.2\%). However, these differences were not statistically significant $(\mathrm{P}=0.320)$. 
Table 1. Foodborne disease outbreaks in Barbados (1998-2009)

\begin{tabular}{|c|c|c|c|c|c|c|c|c|c|c|}
\hline Outbreak & Month / Year & Duration & $\begin{array}{c}\text { Total } \\
\text { cases }(\mathbf{N})\end{array}$ & $\begin{array}{l}\text { Visitor cases } \\
\text { (n) of the total } \\
\text { (N) }\end{array}$ & Causative agent & Implicated foods & Hosp/Deaths & Source/food retail & Setting & $\begin{array}{l}\text { Poly } \\
\text { clinic }^{4}\end{array}$ \\
\hline 1 & August $1998^{1,2}$ & $\dagger$ & 12 & 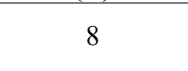 & $\begin{array}{l}S \text {. Enteritidis } \\
\text { Phage type } 8\end{array}$ & $\begin{array}{l}\text { Caesar salad with eggs and } \\
\text { egg glazed pastries }\end{array}$ & $\dagger$ & Suspect hotel restaurant & Hotel & $\dagger$ \\
\hline 2 & October $1998^{2}$ & $\dagger$ & 4 & 0 & $\begin{array}{l}S . \text { Enteritidis } \\
\text { Phage type } 8\end{array}$ & Soft boiled eggs (pooled) & $\dagger$ & Home kitchen & Private home & $\dagger$ \\
\hline 3 & $\underset{2}{\text { November }} 1998^{1}$ & $\dagger$ & 11 & 6 & $\begin{array}{l}S . \text { Enteritidis } \\
\text { Phage type } 8\end{array}$ & $\begin{array}{l}\text { Scrambled eggs with soft } \\
\text { yolk }\end{array}$ & $\dagger$ & Suspect hotel restaurant & Hotel & $\dagger$ \\
\hline 4 & November $1998^{2}$ & $\dagger$ & 2 & 0 & $\begin{array}{l}S \text {. Enteritidis } \\
\text { Phage type } 8\end{array}$ & Raw cake batter & $\dagger$ & Home kitchen & Private home & $\dagger^{\dagger}$ \\
\hline 5 & December $1998^{2}$ & $\dagger$ & 8 & 0 & $\begin{array}{l}S \text {. Enteritidis } \\
\text { Phage type } 4\end{array}$ & Soft boiled eggs & $\dagger$ & Home kitchen & Private home & $\dagger$ \\
\hline 6 & February $1999^{2}$ & $\dagger$ & 3 & 0 & $\begin{array}{l}S \text {. Enteritidis } \\
\text { Phage type } 8\end{array}$ & Fried eggs (soft yolk) & $\dagger$ & Home kitchen & Private home & $\dagger$ \\
\hline 7 & March $1999^{2}$ & $\dagger$ & 4 & 0 & $\begin{array}{l}S \text {. Enteritidis } \\
\text { Phage type } 8\end{array}$ & Scrambled eggs & $\dagger$ & Home kitchen & Private home & $\dagger$ \\
\hline 8 & April $1999^{2}$ & $\dagger$ & 4 & 0 & $\begin{array}{l}S . \text { Enteritidis } \\
\text { Phage type } 8\end{array}$ & Soft boiled eggs pooled & $\dagger$ & Home kitchen & Private home & $\dagger$ \\
\hline 9 & June $1999^{1,2}$ & $\dagger$ & 9 & 4 & $\begin{array}{l}\text { S. Enteritidis } \\
\text { Phage type } 4\end{array}$ & $\begin{array}{l}\text { Suspect fried eggs with soft } \\
\text { yolk }\end{array}$ & $\dagger$ & Suspect hotel restaurant & Hotel/Resort & $\dagger$ \\
\hline 10 & July $1999^{2}$ & $\dagger$ & 5 & 0 & $\begin{array}{l}\text { S. Enteritidis } \\
\text { Phage type } 2\end{array}$ & Undercooked chicken & $\dagger$ & Home kitchen & Private home & $\dagger$ \\
\hline 11 & August $1999^{1,2}$ & $\dagger$ & 8 & 3 & $\begin{array}{l}S . \text { Enteritidis } \\
\text { Phage type } 2\end{array}$ & Undercooked chicken & $\dagger$ & Suspect hotel restaurant & Hotel & $\dagger$ \\
\hline 12 & June $2000^{2}$ & $\dagger$ & 5 & 0 & $\begin{array}{l}S \text {. Enteritidis } \\
\text { Phage type } 4\end{array}$ & Lasagna with eggs & $\dagger$ & Home kitchen & Private home & $\dagger$ \\
\hline 13 & August $2000^{1,2}$ & $\dagger$ & 7 & 3 & $\begin{array}{l}S . \text { Enteritidis } \\
\text { Phage type } 8\end{array}$ & $\begin{array}{c}\text { Caesar salad (contained } \\
\text { eggs) }\end{array}$ & $\dagger$ & Suspect hotel restaurant & Hotel & ${ }^{\dagger}$ \\
\hline 14 & September $2000^{2}$ & $\dagger$ & 3 & 0 & $\begin{array}{l}S \text {. Enteritidis } \\
\text { Phage type } 8\end{array}$ & Soft boiled eggs (Pooled) & $\dagger$ & Home kitchen & Private home & $\dagger$ \\
\hline 15 & November $2000^{2}$ & $\dagger$ & 6 & 0 & $\begin{array}{l}\text { S. Enteritidis } \\
\text { Phage type } 8\end{array}$ & Scrambled eggs & $\dagger$ & Home kitchen & Private home & $\dagger$ \\
\hline 16 & January $2001^{2}$ & $\dagger$ & 4 & 0 & $\begin{array}{l}S \text {. Enteritidis } \\
\text { Phage type } 8\end{array}$ & Soft boiled eggs (pooled) & $\dagger$ & Home kitchen & Private home & $\dagger$ \\
\hline 17 & January $2001^{1,2}$ & $\dagger$ & 6 & 2 & $\begin{array}{l}S \text {. Enteritidis } \\
\text { Phage type } 2\end{array}$ & Undercooked chicken & $\dagger$ & Suspect hotel restaurant & Hotel & $\dagger$ \\
\hline 18 & February $2004^{3}$ & 2 days & 21 & 0 & ++ & $\dagger$ & None & Hospital Kitchen & Hospital & ВТРC \\
\hline 19 & July $2005^{3}$ & $\dagger$ & 25 & 0 & $S$. Typhimurium & Pudding and souse & None & Food vendor & $\begin{array}{l}\text { Food business St. } \\
\quad \text { Michael }\end{array}$ & WSPC \\
\hline 20 & $\begin{array}{l}\text { July, August, } \\
\text { September } \\
2005^{3, R}\end{array}$ & 70 days & 27 & 2 & $\begin{array}{l}\text { S. aureus and } \\
\text { Salmonella spp. } \\
\text { isolated from stools }\end{array}$ & $\dagger$ & None & Hotel restaurant & Hotel, St. Michael & WSPC \\
\hline 21 & April $2006^{3}$ & 2 days & 5 & 0 & S. aureus intoxication & Ham cutters & None & Food vendor & Private Office & ВТPC \\
\hline 22 & September $2006^{3}$ & 2 days & 10 & 10 & $\begin{array}{l}\text { S. aureus intoxication } \\
\text { Salmonella and }\end{array}$ & Beef roti & None & Food vendor & Hotel & ВТРC \\
\hline 23 & October $2006^{3, R}$ & $\dagger$ & 20 & 16 & $\begin{array}{l}\text { Campylobacter } \\
\text { isolated from stools }\end{array}$ & $\dagger$ & None & Hotel restaurant buffet & Hotel, St. Michael & WSPC \\
\hline $\begin{array}{l}24 \\
\text { Tot }\end{array}$ & $\begin{array}{c}\text { February } 2009^{3, \mathrm{R}} \\
24\end{array}$ & $\dagger$ & $\begin{array}{c}6 \\
215\end{array}$ & $\begin{array}{c}0 \\
54\end{array}$ & $\dagger$ & $\dagger$ & One hosp. & Mobile food vendor & Offices, St. Michael & WPC \\
\hline
\end{tabular}




\section{Aetiology of outbreaks}

Bacteria were responsible for $22 / 24(91.7 \%)$ of outbreaks and 188/215 (87.4\%) of cases. The most common bacterial causes of the 24 outbreaks were SE $17 / 24(70.8 \%), S$. aureus - $2 / 24(8.3 \%)$ and mixed infections - $2 / 24(8.3 \%)$, where Salmonella spp. and Campylobacter spp. were isolated from stools in one instance and Salmonella spp. and $S$. aureus were isolated in another. $S$. Typhimurium accounted for $1 / 24$ $(4.2 \%)$ of outbreaks and the aetiology was unknown in $2 / 24(8.3 \%)$ and $27 / 215$ (12.6\%) cases (Table 1). SE was more frequently associated with FBDOs than the other bacteria $\left(\chi^{2}(1)=4.12, \mathrm{P}=0.040\right)$ and it was the most common cause in both hotel and non-hotel outbreaks ( $75 \%$ and $69 \%$ respectively). Of the 17 outbreaks and 101 cases caused by SE, phage type 8 was more significantly associated with FBDO cases $60 / 101$ (59.4\%), followed by phage type $4-22 / 101$ $(21.7 \%)$ and phage type $2-19 / 101(18.8 \%)$. The differences in these frequencies were statistically significant $\left(\chi^{2}(2)=31.00, P=0.000\right)$.

\section{Peak months}

The peak months overall for the 24 outbreaks was August. A majority of hotel outbreaks occurred in
August 4/9 (44.4\%) and a significant majority of nonhotel outbreaks occurred in February - 3/15 (20.0\%) (P $=0.015$ ).

\section{Foods implicated}

Foods of animal origin were significantly implicated, either solely or combined, in most $(19 / 24$, $79.2 \%)$ of the outbreaks $\left(\chi^{2}(1)=8.17, \mathrm{P}=0.004\right)$. For $4 / 24(16.7 \%)$ of the outbreaks, the food source was unknown. Eggs were implicated most commonly in the outbreaks. Undercooked chicken and Caesar salads were also commonly implicated foods in hotel outbreaks.

\section{Outbreak Report Assessments}

For three of the outbreaks (\#20, \#23 and \#24), reports of the investigations were available from the Ministry of Health. The reports demonstrated that there were shortcomings in various aspects of the outbreak investigations such as: the carrying out of in-depth interviews; descriptive/analytical epidemiology; environmental lab studies; resolution of outbreaks and the standard reporting format for the communication of findings (Table 2). Additionally, reports from outbreaks $\# 20$ and \#23, which occurred at two separate hotels,

Table 2. Assessment of investigations for foodborne outbreaks with reports available (1998-2009).

\begin{tabular}{|c|c|c|c|}
\hline Criteria* $^{*}$ & Outbreak \#20 & Outbreak \#23 & Outbreak \#24 \\
\hline \multicolumn{4}{|l|}{ 1. Establish existence of outbreak and verify diagnosis } \\
\hline In depth interviews & Partially $^{* *}$ & Partially & Partially \\
\hline Identification of factors common to cases & Yes & Yes & Yes \\
\hline \multicolumn{4}{|l|}{ 2. Environmental/Site investigation } \\
\hline Inspection of structural and operational hygiene & Yes & Yes & Yes \\
\hline Food processing procedures examined (risk assessment) & Yes & Yes & Yes \\
\hline \multicolumn{4}{|l|}{ 3. Descriptive/Analytical Epidemiology } \\
\hline Case definitions established & Yes & Yes & Partially \\
\hline \multicolumn{4}{|l|}{ Cases categorized by: } \\
\hline Time (with epidemic curve) & Yes & Partially & Partially \\
\hline Place (with spot/area maps) & Partially & Partially & Partially \\
\hline Person & Yes & Yes & Yes \\
\hline Controls established & Partially & No & Yes \\
\hline Population at risk determined & No & No & No \\
\hline Hypothesis generated & Yes & Yes & Yes \\
\hline Attack rates calculated & No & No & Yes \\
\hline Risk calculated (RR/RD/ST) ${ }^{* * *}$ & No & No & Yes \\
\hline \multicolumn{4}{|l|}{ 4. Environmental and Lab studies } \\
\hline Food/environmental samples collected & Partially & Partially & Partially \\
\hline Clinical samples collected from cases & Partially & Partially & Partially \\
\hline 5. Outbreak resolved & Partially & Partially & No \\
\hline \multicolumn{4}{|l|}{ 6. Control measures instituted } \\
\hline Source and transmission & Yes & Not indicated & Not indicated \\
\hline Monitoring/Surveillance & Yes & Not indicated & Yes \\
\hline 7. Findings communicated & Yes & Yes & Yes \\
\hline Standard reporting format & No & No & No \\
\hline
\end{tabular}


documented high counts of indicator organisms in foods such as: Pseudomonas spp. $\left(8 \times 10^{4} \mathrm{cfu} / \mathrm{g}\right)$ and mixed coliforms $\left(1.2 \times 10^{4} \mathrm{cfu} / \mathrm{g}\right)$ in coleslaw; nonhaemolytic Streptococcus spp. in kidney bean salad $(>1$ $\times 10^{5} \mathrm{cfu} / \mathrm{g}$ ); heavy growth of Enterobacter spp. and Bacillus spp. in roast beef, E. coli in smoked salmon and Klebsiella spp. in turkey. There were deficiencies in food processing practices which included poor hygiene practices and inadequate food preparation practices such as poor cold storage of salads; inadequate separation of clean and dirty utensils; improper freeze/thaw practices; improper hot/cold hold practices; improper work restriction polices with regards to ill staff and food being held at room temperature for prolonged periods.

\section{Discussion}

This review of FBDOs in Barbados indicated that during the period 1998-2009, there were 24 reported FBDOs which caused 215 cases of illness, 1 hospitalisation and no deaths. These figures are very low in comparison with data reported by other researchers in developed regions such as the U.S.A, Hong Kong, Macedonia and Australia over a 10-year period [1-6,43-44]. Contrastingly, the number of FBDOs was higher than what was reported from Kenya [7]. Moreover, reports from the Caribbean (1980 2005 ) indicated that the number of FBDOs recorded in Barbados was higher in comparison than FBDOs in other developing islands [11] (Table 3). Ombui et al. [7] surmised that the low number of outbreaks recorded in
Kenya was likely due to severe under-reporting, which was a considerable limitation [7]. Correspondingly, under-reporting was likely to be largely responsible for the low incidence of FBDOs observed in the Caribbean region $[10,11,21]$. In this study, outbreaks were recorded mostly during the summer month of August, which was similar to what was observed in other countries such as the U.S.A, Chile and Iran $[1,8,45]$. The increased level of outbreaks during the summer months is often attributed to the increased ambient temperatures which favour the multiplication of pathogens. Additionally, outdoor activities such as barbecues, which involve the cooking and consumption of food, are conducted more frequently [46]. In Barbados, the summer months also coincide with the annual Crop Over carnival which brings an influx of tourists. This may lead to increased demands being placed on food operators which can result in less attention being paid to proper food hygiene, cooking temperatures and food storage.

Of the 24 outbreaks reported, $45.8 \%$ were associated with food prepared in home kitchens whereas $33.3 \%$ were associated with hotel restaurants. This finding is similar to what was reported in Iran, where households $(52.3 \%)$ were most associated with outbreaks [8]. However, this finding differs with what was observed in the U.S.A, Australia and Hong Kong, where restaurants were the setting most associated with FBDOs $[1,2,6,43]$.

In this review, $83 \%$ of the 24 outbreaks investigated were completely solved. This solve rate is high

Table 3. Global characterisation of FBDOs from various regions.

\begin{tabular}{|c|c|c|c|c|c|c|}
\hline Region & Period & FBDOs & Cases & Hospitalisations & Deaths & Reference \\
\hline U.S.A & 2015 & 902 & 15,202 & 980 & 15 & {$[1]$} \\
\hline \multicolumn{7}{|c|}{ Asia and the Middle East } \\
\hline \multirow{2}{*}{ Hong Kong } & $1995-2005$ & 5967 & 26,260 & 1854 & 0 & {$[2]$} \\
\hline & 2016 & 201 & 1011 & Not reported & Not reported & [3] \\
\hline Iran & $2006-2011$ & 2250 & 46,451 & 6263 & 93 & [8] \\
\hline \multicolumn{7}{|l|}{ Europe } \\
\hline Macedonia & $1998-2008$ & 42 & 1871 & 608 & 0 & [44] \\
\hline \multirow{2}{*}{ Australia } & 2011 & 151 & 2104 & 231 & 5 & {$[6]$} \\
\hline & 2016 & 70 & 1625 & 71 & Not reported & {$[5]$} \\
\hline Caribbean & & & & & & [11] \\
\hline Bermuda & $1980-2005$ & 4 & 109 & Not reported & Not reported & \\
\hline Jamaica & $1980-2005$ & 8 & 319 & Not reported & Not reported & \\
\hline Trinidad and Tobago & $1980-2005$ & 11 & 706 & Not reported & Not reported & \\
\hline Bahamas & $1980-2005$ & 4 & 1307 & Not reported & Not reported & \\
\hline Guyana and Suriname & $1980-2005$ & 3 & 7 & Not reported & Not reported & \\
\hline Turks and Caicos & $1980-2005$ & 5 & 213 & Not reported & Not reported & \\
\hline Barbados & $1980-2005$ & 9 & 83 & Not reported & Not reported & \\
\hline \multicolumn{7}{|l|}{ Africa } \\
\hline Kenya & $1970-1993$ & 13 & 926 & Not reported & Not reported & [7] \\
\hline
\end{tabular}


compared to a range of $30-44 \%$ which was found in a multistate review of outbreaks in the U.S.A. [47]. Generally, outbreaks are considered to be solved if both the food source and pathogen are identified and epidemiologically linked to the outbreak [47]. Therefore, the high frequency of solved outbreaks in this review was unexpected and could be explained, in part, by the fact that $70.8 \%(17 / 24)$ of these outbreaks were recorded during active surveillance for FBDOs and foodborne illness [48].

\section{Enteropathogens and foods implicated}

Salmonella Enteritidis was the most common bacterial aetiology of FBDOs. This contrasts with earlier reports of Salmonella outbreaks from Barbados (1986 - 1993) where Enteritidis was not evident and indicates that the epidemiology has changed [24]. For instance, in 1989 Salmonella St. Paul was responsible for two outbreaks among preschool children; Typhimurium was implicated in an outbreak among tourists in 1991 for which fish salad was the food source; serovar Cerro was implicated in a hotel outbreak in 1992 where pastries glazed with egg white were the food source and in 1993 serovars Thompson and Typhimurium were the causative agents of FBDOs occurring at a hotel and hospital respectively [24].

The predominance of Salmonella spp. as a bacterial cause of FBDOs has varied among worldwide studies [1-4,6-8]. In contrast to the report of this study, in period 1994-1996, Paredes et al. [39] studied TD at five resorts in Negril, Jamaica and discovered that enterotoxigenic $E$. coli was the most common aetiological agent followed by Salmonella spp., Shigella spp. and Campylobacter jejuni. Steffen et al. [37] also described a similar aetiology in their study of TD of 10 large hotels in Jamaica. Likewise, in Iran, E. coli was the predominant cause of FBDOs and Salmonella spp. the fourth most common cause (5.1\%) [8] and in Kenya, S. aureus $(38.5 \%)$, C. botulinum $(10 \%)$ and Clostridium perfringens $(7.7 \%)$ were most implicated in confirmed FBDOs [7]. However, similar to the findings of this study, in the U.S.A, Salmonella was the most commonly reported bacterial etiologic agent, causing $106(25 \%)$ of the confirmed FBDOs attributed to bacteria in the U.S.A in 2012, with Enteritidis being the most common serotype (26\% outbreaks) followed by Typhimurium (13\%) [49]. Salmonella spp. was also the most common bacterial pathogen implicated in outbreaks in Singapore and Australia [4,6].

This review demonstrated that eggs $(41.7 \%)$, undercooked chicken (12.5\%) and Caesar salads with eggs $(8.3 \%)$ were most implicated in outbreaks which is similar to the findings in a study from Australia where the main foods implicated were eggs $(53 \%)$ and poultry (16\%) [6]. However, it differed from what was reported in the U.S.A where fish and poultry were the foods most implicated [1,49] and in Hong Kong [2,3] and Kenya [7] where seafood and milk/milk products were the most implicated foods respectively. SE phage type 8 was most the most common phage type associated with the outbreaks, $(59.4 \%)$ followed by phage type 4 $(21.7 \%$, ) and phage type $2(18.8 \%)$. Similarly, phage type 8 was the most common type associated with foodborne illness in the U.S.A. [50] and Canada [51]. Conversely, in Europe and in the neighbouring island of Trinidad, phage type 4 caused most SE-related foodborne illnesses [52-54]. Furthermore, $S$. Enteritidis prevalence in commercial egg-laying farms on Barbados was found to be high (73\%) [55]. Therefore, it is important to maintain the refrigeration and safe hygienic handling of raw eggs and thoroughly cook them before consumption.

The Noroviruses did not feature as a cause of FBDOs in Barbados for the period of this report. While it could be credible that Noroviruses were not frequently associated with outbreaks in Barbados, there was a lack of consistent laboratory screening for the Norovirus which could have precluded its detection in suspected outbreaks for which a bacterial cause could not be identified. Staphylococcus aureus was the second most common bacteria, suspected in $8.3 \%$ of FBDO in Barbados. This was comparable to findings in the study in Kenya, where S. aureus (38.5\%) was the most common cause of confirmed FBDOs and the second most suspected cause $(10 \%)$ of unconfirmed FBDOs [7].

The review did not identify Campylobacter spp. to be a major cause of outbreaks, which agrees with another study which stated that Campylobacter spp. is no longer a leading cause of foodborne outbreaks worldwide [56]. However, reports exist globally that Campylobacter spp. are still important pathogens responsible for FBDOs [1,4-6,49]. In Barbados Campylobacter was found to be prevalent among children with AGE $[22,23,25]$ which is similar in other developing countries [25]. Furthermore, it was detected in raw chicken samples (58\%) from supermarkets [29]. However, it has been observed that Barbadians thoroughly cook meats prior to consumption and refrain from consuming raw meats [29]. These practices combined with the food safety measures employed by the Barbados Ministry of Health, such as the training of 
food handlers and annual inspections of food businesses may be having an impact on the prevention of FBDOs.

\section{Conclusions}

Twenty-four FBDOs were reported in Barbados for the period 1998 - 2009. This figure is low in comparison to developed countries, however, the data were likely affected by under-reporting, deficiencies in the outbreak investigations and laboratory detection. Therefore, it is recommended that improvements in these areas would lead to better detection and characterisation of FBDOs in Barbados. Furthermore, as the outbreak reports indicated a high level of contamination of some foods with indicator organisms, it is recommended that improvements in hygiene and sanitation practices at food retail operations be made which would improve food safety.

\section{Acknowledgements}

We are grateful to the University of the West Indies St. Augustine Campus Graduate and Research Committee for providing the funds for the project. Dr. Edmund Blades, Stephanie Sobers, Maria Ingram, Tyrone Applewaite and the Public health officers at the Ministry of Health, Barbados are thanked for their assistance in the project.

\section{References}

1. Centers for Disease Control and Prevention (2017) Surveillance for foodborne disease outbreaks, United States, 2015 annual report. US Department of Health and Human Services, CDC, Atlanta, Georgia. Available: https://www.cdc.gov/foodsafety/pdfs/2015FoodBorneOutbrea ks_508.pdf. Accessed: 12 September 2017.

2. Chan SF and Chan ZCY (2008) A review of foodborne disease outbreaks from 1996 to 2005 in Hong Kong and its implications on food safety promotion. J Food Safety 28: 276299.

3. Yau S (2017) Review of foodborne disease outbreaks related to food premises and food business in 2016. Centre for food safety - Food safety focus 129.

4. Kondakci T and Yuk HG (2012) Overview of foodborne outbreaks in last decade in Singapore: Alarming increase in nontyphoidal salmonellosis. In Cabel D and Serra NM, editors. Food and Beverage Asia. Pablo Publishing Pte Ltd., Singapore. $42-45$.

Available: http://www.foodbeverageasia.com/ebook/FBA_DecJan2013/f iles/assets/seo/page44.html. Accessed: 10 December 2017.

5. Communicable Diseases Branch (2017) NSW OzFoodNet annual surveillance report: 2016. Health Protection NSW, Sydney. Available: http://www.health.nsw.gov.au/Infectious/foodborne/Publicati ons/NSW-ofn-annual-report-2016.pdf. Accessed: 12 September 2017.

6. The OzFoodNet working group (2015) Monitoring the incidence and causes of disease potentially transmitted by food in Australia: annual report of the OzFoodNet network, 2011. Commun Dis Intell 39: 236-264.

7. Ombui JN, Kagiko MM, Arimi SM (2001) Foodborne diseases in Kenya. East Afr Med J 78: 40-44.

8. Masoumi AH, Gouya MM, Soltan-Dallal MM, and Aghili N (2015) Surveillance for foodborne disease outbreaks in Iran, 2006-2011. Med J Islam Repub Iran 29: 285.

9. Guerra MMM, de Almeida AM, and Willingham AL (2016) An overview of food safety and bacterial foodborne zoonoses in food production animals in the Caribbean region. Trop Anim Health Prod 48: 1095-1108.

10. Henson S (2003) The economics of food safety in developing countries. Agriculture and Economic Development Analysis Division Working Paper 03-19: 1-100. Available: http://www.fao.org/docrep/pdf/007/ae052e/ae052e00.pdf. Accessed: 12 January 2014.

11. Caribbean Epidemiology Centre (CAREC/PAHO/WHO) (2008) Morbidity review of communicable diseases in CAREC member countries 1980-2005. CARPHA (Caribbean Public Health Agency), 16-18 Jamaica Blvd, Federation Park, Port of Spain, Trinidad \& Tobago.

12. World Health Organization (2015) WHO estimates of the global burden of foodborne diseases. World Health Organization, 20 Avenue Appia, 1211 Geneva 27, Switzerland. Available:http://apps.who.int/iris/bitstream/10665/199350/1/9 789241565165\%5Feng.pdf?ua=1. Accessed: 29 October 2017.

13. Kuchenmüller T, Hird S, Stein C, Kramarz P, Nanda A, Havelaar AH (2009) Estimating the global burden of foodborne diseases -a collaborative effort. Euro Surveill 14: 14.

14. Kuchenmüller T, Abela-Ridder B, Corrigan $\mathrm{P}$, Tritscher A (2013) World Health Organization initiative to estimate the global burden of foodborne diseases. Rev Sci Tech 32: 459467.

15. Persuad S, Mohamed-Rambaran P, Wilson A, James C, Indar L (2014) Determining the community prevalence of acute gastrointestinal illness and gaps in surveillance of acute gastroenteritis and foodborne diseases in Guyana. J Health Popul Nutr 31 Suppl 1: 57-68.

16. Ahmed S, Ricketts P, Bergeron M, Jones W, Indar L (2014) Distribution, burden, and impact of acute gastroenteritis in Dominica, 2009-2010. J Health Popul and Nutr 31 Suppl 1: 4356.

17. Glasgow LM, Forde MS, Antoine SC, Pérez E, Indar L (2013) Estimating the burden of acute gastrointestinal illness in Grenada. J Health Popul Nutr 31 Suppl 1: 17-29.

18. Gabriel OO, Jaime A, Mckensie M, Auguste A, Pérez E, Indar L (2013) Estimating the burden of acute gastrointestinal illness: a pilot study of the prevalence and under-reporting in Saint Lucia, Eastern Caribbean. J Health Popul Nutr 31 Suppl 1: $3-16$.

19. Fletcher SM, Lewis-Fuller E, Williams H, Miller Z, Scarlett HP, Cooper C, Gordon-Johnson KA, Vickers I, Shaw K, Wellington I, Thame J, Pérez E, Indar L (2013) Magnitude, distribution, and estimated level of under-reporting of acute gastroenteritis in Jamaica. J Health Popul Nutr 31 Suppl 1: 6980 .

20. Lakhan C, Badrie N, Ramsubhag A, Sundaraneedi K, Indar L (2013) Burden and impact of acute gastroenteritis and foodborne pathogens in Trinidad and Tobago. J Health Popul Nutr 31 Suppl 1:30-42.

21. Ingram M, St. John J, Applewhaite T, Gaskin P, Springer K, Indar L (2013) Population-based estimates of acute 
gastrointestinal and foodborne illness in Barbados: a retrospective cross-sectional study. J Health Popul and Nutr 31 Suppl 1: 81-97.

22. St. John MA, Lewis DB (1988) Childhood gastroenteritis in Barbados - occurrence of Campylobacter and rotavirus. West Indian Med J 37: 78-83.

23. Applewaite J, Levett PN (2000) Prevalence of Campylobacter species in diarrhoeal stools in Barbados. West Indian Med J 49: 36.

24. Levett PN (1994) Changing epidemiology of Salmonella and Shigella infections in Barbados. B.A.M.P Bulletin 132: 9-12

25. Workman SN, Sobers SJ, Mathison GE, and Lavoie MC (2006) Human Campylobacter-associated enteritis on the Caribbean island of Barbados. Am J Trop Med Hyg 74: 623-627.

26. Adesiyun AA (1995) Bacteriologic quality of some Trinidadian ready-to-consume foods and drinks and possible health risks to consumers. J Food Prot 58: 651- 655.

27. Laloo S, Rampersad FS, La Borde A, Maharaj K, Sookhai L, Teelucksingh JD, Reid S, McDougall L, Adesiyun AA (2000) Bacteriological quality of raw oysters in Trinidad and the attitudes, knowledge and perceptions of the public about its consumption. Int J Food Microbiol 54: $99-107$.

28. Mankee A, Ali S, Chin A, Indalsingh R, Khan R, Mohammed F, Rahman R, Sooknanan S, Tota-Maharaj R, Simeon D, Adesiyun AA (2003) Bacteriological quality of "doubles" sold by street vendors in Trinidad and the attitudes, knowledge and perceptions of the public about its consumption and health risk. Food Microbiol 20: 631-639.

29. Workman SN, Mathison GE, Lavoie MC (2005) Pet dogs and chicken meat as reservoirs of Campylobacter spp. in Barbados. J Clin Microbiol 43: 2642-2650.

30. Gibbons IS, Adesiyun A, Seepersadsingh N, Rahaman S (2006) Investigation for possible source(s) of contamination of ready-to-eat meat products with Listeria spp. and other pathogens in a meat processing plant in Trinidad. Food Microbiol 23: 359-366.

31. Hosein A, Muñoz K, Sawh K, Adesiyun A (2008) Microbial load and the prevalence of Escherichia coli, Salmonella spp. and Listeria spp. in ready-to-eat products in Trinidad. Open Food Sci J 2: 23-28.

32. Workman SN (2008) An investigation of sources of Campylobacter in a poultry production and packing operation in Barbados. Int J Food Microbiol 121: 106-111.

33. Rampersad FS, Laloo S, La Borde A, Maharaj K, Sookhai L, Teelucksingh J, Reid S, McDougall L, Adesiyun AA (1999) Microbial quality of oysters sold in Western Trinidad and potential health risk to consumers. Epidemiol Infect 123: 241250.

34. Syne SM, Ramsubhag A, Adesiyun AA (2013) Microbiological hazard analysis of ready-to-eat meats processed at a food plant in Trinidad, West Indies. Infect Ecol Epidemiol 3: 20450.

35. Hill DR, Beeching NJ (2010) Travellers' diarrhoea. Curr Opin Infect Dis 23: 481-487.

36. Greenwood Z, Black J, Weld L, O'Brien D, Leder K, Von Sonnenburg F, Pandey P, Schwartz E, Connor BA, Brown G, Freedman DO, Torresi J, GeoSentinel Surveillance Network. (2008) Gastrointestinal infection among international travellers globally. J Travel Med 15: 221-228.

37. Steffen R, Collard F, Tornieporth N, Campbell-Forrester S, Ashley D, Thompson S, Mathewson JJ, Maes E, Stephenson B, DuPont HL, von Sonnenburg F (1999) Epidemiology, aetiology, and impact of travellers' diarrhoea in Jamaica. JAMA 281: $811-817$.

38. Ashley DVM, Walters C, Dockery-Brown C, McNab A, and Ashley DEC (2004) Interventions to prevent and control foodborne diseases associated with a reduction in travellers' diarrhoea in tourists to Jamaica. J Travel Med 11: 364 - 367.

39. Paredes P, Campbell-Forrester S, Mathewson JJ, Ashley D, Thompson S, Steffen R, Jiang ZD, Svennerholm AM, DuPont HL (2000) Aetiology of travellers' diarrhoea on a Caribbean Island. J Travel Med 7: $15-18$.

40. Marshall CA, Morris E, Unwin N (2016) An epidemiological study of rates of illness in passengers and crew at a busy Caribbean cruise port. BMC Public Health 16: 314.

41. Hull-Jackson C, Adesiyun AA (2018) Visitor perceptions of food safety and sociodemographic determinants in Barbados, West Indies. J Food Prot 81: 2064-2073.

42. World Travel and Tourism Council (2017) Travel \& tourism economic impact 2017-Barbados. Available: https://www.wttc.org/-/media/files/reports/economic-impactresearch/countries-2017/barbados2017.pdf. Accessed: 24 December 2017.

43. Centres for Disease Control and Prevention (2013) Surveillance for foodborne disease outbreaks-United States, 1998-2008. MMWR Surveill Summ 62: 1 - 34.

44. Kendrovski V, Karadzovski Z, Spasenovska M (2011) Ambient maximum temperature as a function of Salmonella food poisoning cases in the Republic of Macedonia. N Am J Med Sci 3: 264-267.

45. Olea A, Díaz J, Fuentes R, Vaquero A, García M (2012) Foodborne disease outbreaks surveillance in Chile. Rev Chilena Infectol 29: $504-510$.

46. Ravel A, Smolina E, Sargeant JM, Cook A, Marshall B, D. Fleury M, and Pollari F (2010) Seasonality in human salmonellosis: assessment of human activities and chicken contamination as driving factors. Foodborne Pathog Dis 7: 785-794.

47. Smith De Waal C, Klein SA, Catella C, and Roberts C (2011) All over the map: a 10-year review of state outbreak reporting including a report card on 50 states and Washington D.C. C.S.P.I (Center for Science in the Public Interest). Available: https://cspinet.org/sites/default/files/attachment/alloverthemap .pdf. Accessed: 3 October 2014.

48. Indar-Harrinauth L, Levett P, Knight R, Baccus-Taylor G, Comissiong E, Hospedales J, Prabhakar P (2002) Changing epidemiological patterns of Salmonella serotype Enteritidis in Barbados. In proceedings of the International Conference on Emerging Infectious Diseases (Foodborne and Waterborne Illness I). Atlanta, Georgia: US Department of Health and Human Services, CDC. Available: ftp://ftp.cdc.gov/pub/infectious_diseases/iceid/2002/pdf/indar. pdf. Accessed: 15 January $201 \overline{5}$.

49. Centers for Disease Control and Prevention (2014) Surveillance for foodborne disease outbreaks, United States, 2012, annual report. Atlanta, Georgia: US Department of Health and Human Services, CDC. Available: http://www.cdc.gov/foodsafety/pdfs/foodborne-diseaseoutbreaks-annual-report-2012-508c.pdf. Accessed: 16 January 2015.

50. Altekruse S, Koehler J, Hickman-Brenner F, Tauxe RV, Ferris K (1993) A comparison of Salmonella Enteritidis phage types from egg-associated outbreaks and implicated laying flocks. Epidemiol Infect 110: $17-22$. 
51. Khakhria R, Duck D, Lior H (1991) Distribution of Salmonella Enteritidis phage types in Canada. Epidemiol Infect 106: 25 32.

52. Fantasia M, Filetici E (1994) Salmonella Enteritidis in Italy. Int J Food Microbiol 21: 7-13.

53. Gillespie IA, O'Brien SJ, Adak GK, Ward LR, and Smith HR (2005) Foodborne general outbreaks of Salmonella Enteritidis phage type 4 infection, England and Wales, 1992-2002: where are the risks? Epidemiol Infect 133: 795 - 801.

54. Indar-Harrinauth L, Daniels N, Prabhakar P, Brown C, BaccusTaylor G, Comissiong E, Hospedales, J (2001) Emergence of Salmonella Enteritidis phage type 4 in the Caribbean: casecontrol study in Trinidad and Tobago, West Indies. Clin Infect Dis 32: $890-896$.

55. Aimey V, Hunte K, Whitehall P, Sanford B, Trotman M, Delgado A, Lefrancois T, Shaw J, Hernandez J (2013) Prevalence of and examination of exposure factors for Salmonella on commercial egg-laying farms in Barbados. Prev Vet Med 110: 489 - 496.
56. Altekruse SF, Stern NJ, Fields PI and Swerdlow DL (1999) Campylobacter jejuni - an emerging foodborne pathogen. Emerg Infect Dis 5: 28 - 35 .

57. World Health Organization (2008) Foodborne disease outbreaks: guidelines to investigation and control. World Health Organization, 20 Avenue Appia, 1211 Geneva 27, Switzerland. Available: http://www.who.int/foodsafety/publications/foodborne_diseas e/outbreak guidelines.pdf. Accessed: 30 October 2017.

\section{Corresponding author}

Dr. Carol Hull-Jackson, D.V.M, MPhil, Ph.D.

School of Veterinary Medicine, Faculty of Medical Sciences, University of the West Indies, St. Augustine, Trinidad, West Indies.

Tel: +6583085968

Email: dr_hull@yahoo.com

Conflict of interests: No conflict of interests is declared. 